\title{
19. Ethnic Voting and Asylum Issues
}

\author{
James Jupp
}

In many democratic societies there is a strong tendency for voters from ethnic or religious minorities to support the party of the 'left', however this may be locally defined. This was initially noticed in the United States, where it is an important concern of political scientists and partisans. Similar trends are noticeable in Britain, Canada, Australia and New Zealand. In the seats where immigrant communities have concentrated, ethnic minority support for the ALP is consistently strong (Jupp 1981 and 1984). This support was largely sustained in 2013, despite general swings towards the Liberals. This chapter argues that predictions of a 'wipeout' for Labor in such electorates were unsound, both in Sydney and Melbourne. It does not argue for the overall impact of 'ethnic and immigration issues' as these were heavily focused on asylum seekers rather than immigration as a whole. Campaigning on such issues was aimed at the AngloAustralian majority. There was very little academic or journalistic debate on immigration issues, as both major parties were in full agreement on 'stopping the boats'.

The two tables in this chapter are both based on the Commonwealth Census of 2006, adjusted to concentrate on those electorates previously described as 'ethnic'. These are defined as having populations in which more than 25 per cent use a language other than English at home. They are confined to Sydney and Melbourne, but constitute almost 20 per cent of the total being contested for the House of Representatives. Significantly they also include nearly all the electorates normally regarded as safe for the ALP; without them Labor would be in permanent opposition. This cannot prove that an 'ethnic vote' exists or is predominantly Labor, but it does suggest that without this reserve (and the Green preferences) there is little hope of change from conservative government nationally and in at least four of the states. 
Abbott's Gambit: The 2013 Australian Federal Election

Table 1: Commonwealth elections of 2010 and 2013 in 'ethnic' electorates (defined as those with 25 per cent or more using a language other than English (LOTE) at home)

\begin{tabular}{|c|c|c|c|}
\hline Electorate & Result 2013 & Labor preferences $(\%)$ & Swing to Liberals 2010-13 (\%) \\
\hline \multicolumn{4}{|c|}{ New South Wales (Boundaries of 22/12/2009) } \\
\hline Banks & Labor loss & 48.07 & +3.47 \\
\hline Barton & Labor loss & 49.55 & +7.45 \\
\hline Bennelong & Liberals retain & 41.97 & +4.91 \\
\hline Blaxland & Labor retains & 62.20 & +0.03 \\
\hline Chifley & Labor retains & 61.11 & +1.36 \\
\hline Fowler & Labor retains & 68.12 & -8.97 \\
\hline Grayndler & Labor retains & 50.48 & -0.03 \\
\hline Greenway & Labor retains & 53.73 & -2.65 \\
\hline Kingsford Smith & Labor retains & 53.19 & +2.10 \\
\hline McMahon & Labor retains & 55.85 & +2.21 \\
\hline Parramatta & Labor retains & 50.78 & +4.10 \\
\hline Reid & Labor loss & 49.36 & +3.50 \\
\hline Watson & Labor retains & 57.5 & +1.57 \\
\hline Werriwa & Labor retains & 52.65 & +4.26 \\
\hline \multicolumn{4}{|c|}{ Victoria (Boundaries of 24/12/2010) } \\
\hline Batman & Labor retains & 61.97 & -4.17 to Greens \\
\hline Bruce & Labor retains & 51.34 & +6.40 \\
\hline Calwell & Labor retains & 63.88 & +6.18 \\
\hline Chisholm & Labor retains & 51.70 & +4.39 \\
\hline Gellibrand & Labor retains & 66.79 & +7.48 \\
\hline Gorton & Labor retains & 66.52 & +7.10 \\
\hline Holt & Labor retains & 60.56 & +4.10 \\
\hline Hotham & Labor retains & 57.64 & +6.47 \\
\hline Isaacs & Labor retains & 53.66 & +6.70 \\
\hline Lalor & Labor retains & 62.11 & +10.01 \\
\hline Maribyrnong & Labor retains & 61.53 & +6.00 \\
\hline Melbourne & Greens retain & 45.11 & -1.10 to Greens \\
\hline Menzies & Liberals retain & 35.97 & +5.75 \\
\hline Scullin & Labor retains & 64.63 & +5.91 \\
\hline Wills & Labor retains & 70.56 & +2.98 \\
\hline \multicolumn{4}{|c|}{ Northern Territory (Boundaries of September 2008) } \\
\hline Lingiari & Labor retains & 51.07 & +2.66 \\
\hline
\end{tabular}

Note: (Most LOTEs in Lingiari are Aboriginal languages)

Source: Australian Electoral Commission (September 2013). 
However, nothing lasts forever. At each election those voting are not identical with those who voted last time, nor are the electoral boundaries unchanged. Much prediction, based on uniform national swings, ignores this. Moreover, with a system of transferred preferences (as in Australia) opinion polling can be misleading. Post-election analysis after this election admitted that predictions of a Labor 'wipeout' were wrong, especially the myth of the collapsing Labor heartland of western Sydney. Labor certainly lost and richly deserved to do so (Patrick 2013). But its reliance on the ethnic minorities remained, consistent with the situation in other stable democratic systems. While the Labor primary vote was unsustainably low, Australian elections are won on seats held, not on simple majorities. Of 17 seats lost by Labor only three had large ethnic minorities (Banks, Barton and Reid).

\section{Migration}

Immigration is often one of the important, but not dominant, election issues. In 2013 refugees occupied a more central place than immigration numbers or sources. Migration had risen to record levels, without prompting the reaction that Australia was 'full up' as in the past. Labor and the unions were concerned with the numbers being brought into Australia on 457 temporary employment visas. While these were important for the expanding mining operations, many were for less obvious needs such as catering and hospitality. The Liberals responded to employer needs by shifting the intake once more towards skills and employment and away from family reunion and especially refugees and asylum seekers under the UN Convention. The Coalition slogan of 'stop the boats', and its labelling of non-visa arrivals by sea as 'illegal', was thought to be a major issue in the western Sydney suburbs where there was a mix of Australian born and recent arrivals and a strong concentration of Muslims in Blaxland, Parramatta and Watson. There was no comparable situation in Melbourne or anywhere else.

Journalists, broadcasters, party officials, candidates and pollsters had all convinced themselves that there was an explosive situation in western Sydney which would be seriously damaging to Labor. What this overlooked was that the large 'ethnic' electorate might not share the same concerns as the Englishspeaking majorities and that Labor-held seats often had a very strong residue of habitual Labor voters which would be hard to overturn. The prediction of a Labor 'wipeout' held for Banks, Barton and Reid, but not for another 10 strongholds in Sydney's west, and not for any comparable seats in Melbourne. Swings there certainly were, but 'wipeouts' did not materialise. Given the state of academic research on voting behaviour, there is still very little evidence of the response of immigrants to immigration issues. There might well be a sense 
that the Liberals are less sympathetic to migrants than the ALP. But the Liberals ran more 'ethnic' candidates and Labor refugee policy had moved very close to the Liberals under Rudd and Gillard.

\section{The 'migrant vote'}

Australian national elections are based on compulsory voting with universal suffrage for all citizens in equalised single member electorates for the lower house, in which control of a government majority resides. As more than one-quarter of Australians were born outside the country, this should give considerable power to a 'migrant vote'. However, there is a considerable gap between the proportion of immigrants and the proportion of elected representatives (Jupp 2004). When compared with other English-speaking democracies, such as the UK, US, Canada or New Zealand, the representation of ethnic minorities in Australia is still marginal, especially at the national lower house level. Moreover, frequently quoted figures exaggerate the strength of 'ethnics' by including all migrants. Of these, over 1.5 million are English speakers from the UK, New Zealand and other similar societies, who are not usually regarded as 'ethnics', especially by themselves. A recent increase in temporary 457 visas, student, working holiday and refugee bridging visas (all without voting rights) tends to distort the 'ethnic' composition of electorates. One useful statistic is available in census data for those 'speaking a language other than English (LOTE) at home', which includes second and subsequent generations who are citizens by birth.

\section{Table 2: Major language groups in 'ethnic electorates' of Sydney and} Melbourne ${ }^{1}$

\begin{tabular}{|l|l|}
\hline \multicolumn{2}{|l|}{ Sydney (Boundaries of 22/12/2009) } \\
\hline Banks & Chinese 30,118; Arabic 8,127; Greek 7,294 \\
\hline Barton & $\begin{array}{l}\text { Greek 16,424; Chinese 14,848; Arabic 11,205; Indian Languages 6,756; } \\
\text { Macedonian 5,513 }\end{array}$ \\
\hline Bennelong & Chinese 26,741; Korean 6,803 \\
\hline Blaxland & Arabic 36,697; Chinese 12,709; Vietnamese 17,059 \\
\hline Chifley & Indian Languages 14,153; Tagalog 9,041; Arabic 6,498 \\
\hline Fowler & $\begin{array}{l}\text { Vietnamese 29,846; Chinese 13,460; Arabic 9,936; Khmer 5,775; Serbian } \\
4,963\end{array}$ \\
\hline
\end{tabular}

\footnotetext{
1 Notes to Table 2: Chinese is divided in the census between Mandarin (mainly from China and Taiwan), and Cantonese (mainly from Southeast Asia, Hong Kong and the long resident Chinese Australians). Indian languages normally include Hindi, Bengali, Punjabi, Urdu. Tagalog includes Filipino. Only languages totalling more than 5,000 speakers are included. NB: these figures are of inhabitants, including children over the age of five, and not of voters. 'Ethnic electorates' are defined as having more than 25 per cent speaking a language other than English at home. These are not necessarily qualified voters and they are not necessarily of overseas birth or nationality. No official figures are available for citizenship by ethnicity.
} 


\begin{tabular}{|c|c|}
\hline \multicolumn{2}{|c|}{ Sydney (Boundaries of 22/12/2009) } \\
\hline Grayndler & Chinese 9,118; Greek 6,375; Italian 5,762 \\
\hline Greenway & Indian Languages 14,362; Vietnamese 5,919 \\
\hline $\begin{array}{l}\text { Kingsford } \\
\text { Smith }\end{array}$ & Chinese 13,691; Greek 7,015 \\
\hline McMahon & $\begin{array}{l}\text { Arabic 11,646; Assyrian 11,326; Chinese 5,775; Italian 5,120; Vietnamese } \\
8,601\end{array}$ \\
\hline Parramatta & $\begin{array}{l}\text { Chinese 20,041; Indian Languages 17,500; Vietnamese 7,714; Arabic } \\
14,111\end{array}$ \\
\hline Reid & $\begin{array}{l}\text { Chinese 25,585; Indian Languages 9,572; Korean 8,911; Italian 7,839; } \\
\text { Greek 9,864 }\end{array}$ \\
\hline Watson & $\begin{array}{l}\text { Arabic 30,768; Chinese 19,470; Indian Languages 13,907; Vietnamese } \\
6,120\end{array}$ \\
\hline Werriwa & Indian Languages 12,608; Arabic 9,526 \\
\hline \multicolumn{2}{|c|}{ Melbourne (Boundaries of 24/12/2010) } \\
\hline Batman & Italian 11,361; Greek 10 126; Chinese 6445; Indian Languages 5095 \\
\hline Bruce: & $\begin{array}{l}\text { Chinese 13,733; Vietnamese 7,886; Indian Languages 6,489; Greek 6,037; } \\
\text { Turkish 5,025 }\end{array}$ \\
\hline Calwell & Turkish 13,681; Arabic 13,023; Assyrian 7,320; Italian 6,505 \\
\hline Chisholm & Chinese 23,554; Greek 6,668 \\
\hline Gellibrand & Vietnamese 9,$992 ;$ Chinese 6,608 \\
\hline Gorton & $\begin{array}{l}\text { Vietnamese 17,049; Tagalog 6,312; Indian Languages } 7,361 ; \text { Chinese } \\
\text { 7,123; Macedonian 6,455; Greek 5,725; Maltese 5,511; Italian 5,069 }\end{array}$ \\
\hline Holt & Chinese 5,051; Sinhalese 5,039 \\
\hline Hotham & Greek 9,857; Chinese 9,468; Vietnamese 6,872; Indian Languages 5,211 \\
\hline Isaacs & Vietnamese 6,041 ; Chinese 5,346 \\
\hline Lalor & Indian Languages 9,786; Chinese 5,678 \\
\hline Maribyrnong & Vietnamese 12,067; Italian 9,283; Chinese 4,591 \\
\hline Melbourne & Chinese 17,858 ; Vietnamese 5,438 \\
\hline Menzies & Chinese 16,963; Greek 7,940; Italian 5,886 \\
\hline Scullin & Italian 9,623; Macedonian 9,043; Greek 6,905; Arabic 6,611 \\
\hline Wills & Italian 14,292; Arabic 8,420; Greek 8,050; Indian Languages 6,387 \\
\hline
\end{tabular}

Source: Parliament of Australia Research Paper: Electoral division rankings: 2006 census (2009 electoral boundaries). Figures based on Australian Bureau of Statistics, 2011 Census Quick Stats and still liable to revision.

This official statistic is elsewhere as defining 'ethnic electorates' when it exceeds 25 per cent of the population. Electorates meeting that criterion are confined to Sydney and Melbourne and numbered 29 (19.3 per cent) in 2013, although there are slightly smaller pockets in Adelaide, Brisbane and Perth. The census of 2011 showed a total of 23 per cent of the population using a language other than English at home, with over 25 per cent for Victoria and New South Wales. These figures have been reorganised into electoral boundaries for the 2013 election by the Parliamentary Library in Research Paper no. 18, 2009-10. There is also 
a wealth of census data arranged for electorates by the Australian Bureau of Statistics and voting by polling stations by the Australian Electoral Commission. While this information is of world standard and very useful to journalists and parties, it is not used by academics as much as it should be. There are no useful official figures for citizens by ethnicity, only by birthplace and religion.

Election results since the readoption of mass immigration in the 1950s show clearly that no effective parties have formed around an ethnic or religious base and related issues, with the exception of the Democratic Labor Party (DLP), which was predominantly Catholic in membership and support. Parties other than the two major contestants - the Australian Labor Party (ALP) and the Liberal Party - have had very limited electoral support for a century. In recent years the One Nation party of Pauline Hanson was strongly but briefly supported in Queensland. All lesser parties reached a vote ceiling of less than 20 per cent and then declined into oblivion. The entirely new Palmer United Party achieved over 600,000 votes (5.53 per cent) at its first outing, which nobody had predicted except Clive Palmer himself. Among the plethora of minor candidates in 2013 only one represented ethnic or religious minorities (Aborigines rather than immigrants).

The strongest minority party, the Greens, are well represented in upper houses elected by proportional representation, but also have a national ceiling of less than 15 per cent. In 2010 and 2013 they held the seat of Melbourne, where 29.2 per cent of the population spoke a language other than English at home. This seat has a very high number of university graduates and a young and transient population. It would be dubious to assume that the Melbourne Greens relied heavily on immigrant voters, although they had a strong following in Richmond and Flemington, parts of which are less gentrified than Fitzroy or Carlton and have substantial ethnic minority populations. The Greens also recorded good returns in those parts of Batman and Wills close to the Melbourne border and long occupied by Italian and Greek settlers. Despite their strong stand on asylum seekers, the Greens usually do no better among immigrant communities than elsewhere.

There is no lasting and consolidated constituency which has produced rivals to the two main parties, either on an ethnic, national or state basis. The prospect for any party based primarily on immigrants is bleak. None have ever succeeded since Federation. The DLP recruited considerable support for a while from refugees from communism who arrived in Australia between 1947 and 1953. The majority of these were Catholics and they were mainly in Victoria. These Eastern Europeans are now an ageing constituency. The ethnic composition of the Green vote is quite unknown, as nobody seems to have asked. Ethnic representation rests with the ALP and the Liberals. Most analysis suggests that Labor has won 'ethnic votes' in working class seats in Sydney and Melbourne, 
but with Anglo-Australian candidates. Several British migrants have been elected, especially in South and Western Australia, and included the Prime Minister Julia Gillard from 2010 to 2013. Until 2013 the Liberals held very few seats with large immigrant concentrations, but were starting to nominate more migrant and 'ethnic' candidates than Labor in winnable seats. This was already apparent in the 2010 general election (Jupp 2012). Aboriginal voters are concentrated north of the Tropic of Capricorn. Their voters tend towards Labor in remote areas served by mobile polling booths, especially in the Northern Territory seat of Lingiari, which remained with Labor. Aboriginal prominent members have often been politically volatile. There had been a big swing to the Country Liberal Party (CLP) among Aboriginal voters in the 2012 Northern Territory election.

The 'ethnic vote', then, appears to be limited to the major cities in its impact, but favourable to the ALP where concentrated. This judgment must rest on election results, rather than opinion polling, although some surveys support it. There are many complexities in measuring the 'ethnic' vote. These include varying levels of naturalisation, which are highest among former refugees; shifting movements from the inner to the outer suburbs; very many distinct ethnicities and religions even from single birthplaces; the maintenance of cultural differences among Australian-born descendants; differing levels of assimilation and language loss; and political rivalries based on overseas traditions. Creating a viable sample at a reasonable cost has evaded pollsters (McAllister 2011). Attempts have been made in recent Australian Election Study polls to create enhanced samples which reach minorities. The same technique has been used by Andrew Markus in his Mapping Social Cohesion reports (Markus 2013). There are a growing number of young immigrants residing here on student or 457 visas who have not yet become citizens, although they are counted in the census. This is particularly relevant to Indian and Chinese residents, who are now more numerous than Europeans in some metropolitan districts.

The basic problems in measuring the 'ethnic' constituency are that it is internally very varied and may behave differently from state to state. It has also been changing its character over the past 20 years, due to changes in the selection criteria for immigrants. These have shifted the emphasis from European manual workers to Asian skilled workers. Naturalisation levels are very high, but a minimum of four years in Australia is required for citizenship. While the degree of allegiance of southern Europeans (Greek, Italian, Maltese, Orthodox Slavs) to Labor is reasonably well established, the same cannot be said for Chinese, Indians, Singaporeans, Koreans, Indochinese or Sri Lankans. The assumption that Muslims gravitate towards Labor has scarcely been tested and covers a wide variety of different nationalities. Blaxland, with a Muslim population of 22.7 per cent, recorded an almost negligible swing to the Liberals in 2013, 
remaining safe for the ALP despite some pre-election predictions of a possible Labor loss. Calwell in Melbourne (15.9 per cent Muslim) also remained safe. Recently the Lebanese Muslim Association of Sydney has shifted its support towards the Liberals (Jakubowicz 2013).

'Ethnicity' is not confined to the immigrant generation. The children of immigrants do not necessarily remain in the places of first immigrant settlement, nor do they self-evidently vote the same way as their parents or grandparents. English-speaking immigrants do not only come from Britain and New Zealand, even if these constitute one-quarter of the 'overseas born'. 'Ethnic communities' are cut by religious divisions, notably amongst the Arabs, the South Slavs, the Vietnamese, the Koreans, the Indians and the Chinese. Sampling such a varied population may be less informative than 'street wise' local knowledge, which depends on effective local party and ethnic organisations. One must, therefore, assume that local knowledge and unpublished party research was leaking to the media with tales of a Labor wipeout in previously safe electorates. This was reinforced by previous election defeats in New South Wales and the Northern Territory. It created the myth of the dying Labor heartland. This was still puzzling commentators on the $\mathrm{ABC}$ election night program and being repeated in the Murdoch press, even after the polls closed (Cater 2013). Of those here defined as 'ethnic electorates', Labor lost three in Sydney (Barton, Reid and Banks) and none at all in Melbourne (see Table 1 above). Labor total losses were 17 electorates, most with small immigrant populations except for Hindmarsh. Half of these were in New South Wales, for understandable reasons (Patrick 2013).

\section{Asylum seekers as a major issue}

'Ethnic electorates' are confined to Sydney and Melbourne and the electoral struggle over immigrant and 'ethnic' issues also takes place largely in Sydney and Melbourne. It was muted during this campaign by the high degree of agreement between the two major parties and their common obsession with asylum seekers. ${ }^{2}$ In the recent past, One Nation could mobilise considerable support, ably assisted by the tabloid press and talkback radio. But much of that ground had been occupied by the Liberals under John Howard and, increasingly on refugee issues, by Labor under Julia Gillard. The ultimate desertion of the UN Convention on Refugees was sealed in May, with Labor hastily legislating to remove mainland Australia from the 'migration zone'. This followed on from its extension of the 'no advantage principle', which punished asylum seekers arriving by boat with the same delays in processing and detention they would

2 For the Coalition's policy, see Liberal Party of Australia/National Party of Australia (2013); Labor's media releases and transcripts on asylum seekers are collected together under the broader topic of immigration at: <pandora.nla.gov.au/pan/22093/20130906-0237/www.alp.org.au/campaign_media_immigration.html>. 
have suffered if they had utilised legal channels to obtain a refugee visa. These delays can run into years. By removing the whole of Australia from the "migration zone' those arriving by boat were further penalised by being denied processing and legal appeals on the mainland. They were to be sent directly to Manus Island (Papua New Guinea) and Nauru. The Liberals endorsed these changes with glee. They had failed to get similar provisions through parliament because of previous Labor and Green opposition. Only the Greens stood firm. Labor voters 'landed on both sides of the debate' with Coalition voters 'comfortably aligned with party policy' (ABC 2013). Australia became the only signatory to the Convention to remove the whole of its territory from the processing system. This avoided the ultimate solution of leaving the Convention altogether, which required a waiting period of a year and would have been embarrassing to Australia as a newly elected chair of the UN Security Council.

While much heat has been generated around the asylum seeker issue, immigration does not normally figure as a dominant issue in national or state opinion polling (McAllister 2003). Thus there are few reliable ways of knowing how 'ethnic' voters feel and behave, except through journalistic impressions or focus groups. These were claiming that asylum seekers were a hot issue in the 'western suburbs' of Sydney, which are among the most 'ethnic' seats in Australia. But their definition of 'western suburbs' often included areas like Penrith (Lindsay) and Campbelltown (Macarthur), which do not have large immigrant populations, and Greenway and Bennelong, which are basically middle class. Nor was there enough difference between the two major parties for a clear-cut choice. The major influences in this region are said to be the (Murdoch) Daily Telegraph, Alan Jones and Ray Hadley (both of radio 2GB), all of them fanatically anti-Labor and hostile to asylum seekers. None of these have established much of a following in Melbourne. After the election Bob Carr added his voice to the view that the asylum seeker issue was vital in Labor's 'collapse', without giving any supporting evidence.

Party policies towards asylum seekers had hardened since 1991 with the introduction by ALP minister Gerry Hand of mandatory and irrevocable detention. This was in reaction to a sudden surge in asylum seekers from Cambodia fleeing the terror campaigns of the Khmer Rouge. The genocidal nature of this regime was not fully revealed at the time. While this new policy might have been planned as temporary it has remained in force ever since, with increasing severity (Simms and Wanna 2012: 268-9). Numbers rose as severe crises struck Afghanistan, Iraq and Sri Lanka. The focal point for landings and detention became Christmas Island, which was relatively easy to reach from Indonesia and Sri Lanka. Indonesia's liberal policy towards Muslim immigrants made it the main point of departure. With increasing controversy about the viability and expense of detention centres on the Australian mainland, Australia 
sought to arrange for several client states to house asylum seekers on their territories with Australian financial and organisational support. East Timor refused to do so, on the reasonable grounds that it was very poor and had many of its own refugees arising from its separation from Indonesia. The Gillard Government developed a plan with Malaysia that would have allowed qualified refugees to be transferred from Malaysia to Australia in exchange for a smaller number who had arrived by boat and would be sent to Malaysia. But the only agreements that came to fruition were for the use of Nauru and Manus Island. Indonesia remained opposed to similar schemes, but gave some undertakings to discourage departures towards Australia.

All these schemes were arguably in breach of the UN Convention on Refugees, of which Australia and New Zealand were the sole signatories in the South Pacific region. Nauru, which is completely dependent on Australia financially, was persuaded to adhere, but Indonesia and Malaysia were not. As one of the smallest and most isolated sovereign states in the world, Nauru seemed an ideal place to remove asylum seekers to. But the logistics of sending refugees, guards, settlement and medical personnel thousands of miles across the ocean proved very expensive and the unhappiness of those dispatched proved very disturbing to the peace of the tiny island. The broad agreement between the main parties that the boats should be stopped and the passengers removed from Australia did not prevent the Greens and many NGOs, academics and lawyers from regular denunciation of bipartisan policies. The main thrust of the Liberal accusation was that the Rudd Government had encouraged the boats by liberalising some of the provisions made by its Coalition predecessor. This may well have been true, but ignored the fact that these changes were more in keeping with the aims of the UN Convention than the alternatives formerly and subsequently implemented. As the election drew nearer both parties escalated their approach. Kevin Rudd claimed that nobody arriving by boat would ever be allowed to secure permanent residence in Australia, which was absurd. Tony Abbott concentrated on the use of Nauru, which was already straining at the seams. However, unlike John Howard, Abbott was not hostile to multiculturalism.

In contrast to Britain and most of Europe there are no Australian parties with electoral support campaigning specifically against immigration, asylum and Muslims. With the passing of One Nation, there was only Pauline Hanson continuing her lonely battle to acquire public funds by contesting elections. The main difference between the major contestants was their competition over who had done better in 'stopping the boats'. On that basis the Liberals were always well ahead, although Kevin Rudd's 'PNG solution' seems to have started working to a limited extent during its short life. This would have settled 'genuine' asylum seekers on Manus Island or elsewhere in Papua New Guinea at Australian expense, but with no right to resettle in Australia. In the rarely 
used argument about who had upheld the UN Convention, only the Greens had much to claim, especially after the total excision of Australia from the "migration zone'. Labor simply moved from the liberal approach of Senator Chris Evans in 2010 to the hard-nosed approach of Chris Bowen in the final months of the campaign.

There were, however, a number of organisations criticising Islam, opposing further immigration and calling for the end of multiculturalism. These included the Q Society of Australia, the Salt Shakers, Rise Up Australia and the Stable Population Party. Registered parties specifically opposing Islam, current immigration levels or multiculturalism scored very marginal Representative votes nationwide: One Nation $(20,621)$, Rise Up Australia $(44,845)$, Australia First $(6,550)$, and Stable Population $(3,582)$. Other parties broadly on the right attracted almost one million votes, the largest number being for the Palmer United Party and Katter's Australia Party. Both of these won a lower house seat each in Queensland with very little defined policy. The PUP also won places in the Senate, promising to make things difficult for the government of the day. Neither Palmer nor Katter had detailed policies on immigration or refugees. Palmer suggested flying asylum seekers to Australia for clearance, ending the offshore detention policy endorsed by the Coalition and Labor. This would certainly be cheaper than current policies backed by government and opposition.

\section{The myth of the 'failing' Sydney heartland}

The electoral picture in 2010 had been comparatively simple: concentrations of 'ethnic' Australians, including Muslims, Catholics, Asians or Europeans, were to be found predominantly in Labor-represented electorates; British origin majority Australians were to be found most strongly represented in rural, provincial and upper suburban Liberal electorates (Jupp 2012). This basic division was sustained to a significant extent by social, class and occupational factors. The pattern was also clear in the Victorian state elections of 2010. Of 37 seats with more than 25 per cent speaking a language other than English at home, 28 were held by Labor and nine by the Liberals. Of these, four were gains from the ALP. This meant that two-thirds of all Victorian Labor seats were from 'ethnic' electorates, compared with only one-fifth of the Liberals. The same happened nationally in 2013, after the most turbulent period in recent Australian politics and an often divisive and embittered national quarrel about immigration and population. There was much publicised panic about Labor losing Sydney's western suburbs, but little concern about comparable threats in Melbourne, where no comparable seats were lost. This panic proved exaggerated, as only Barton, Reid and Banks were lost in 'ethnic' Sydney, together with marginal 
Lindsay, which does not have a high immigrant population. However, it is possible that 'ethnic voters' in Sydney were more dissatisfied than in Melbourne. In particular, the large Chinese communities seemed disaffected, failing even to elect the distinguished Chinese Labor candidate in Bennelong, Jason Yat-Sen Li. Barton, Reid and Banks all had particularly large Chinese-speaking populations. Each also had water frontages with new middle class housing projects. Tony Abbott's early boast that he would have 'several' Nguyens in his parliamentary party was not sustained. None of the three Vietnamese Liberals with that name were elected, even in Fowler, the most Vietnamese electorate in Australia. One, Andrew Nguyen, complained of being treated as a 'second-class citizen' by Liberal organisers in Fowler (Aston 2013).

The concerted Liberal attempt to promote successful 'ethnic' candidates was generally a failure, except in Barton. With more Greek speakers $(16,424)$ than even the better-known Greek strongholds of Melbourne, this mixed bayside suburb was taken from years of Labor control by a Greek-Australian Liberal, despite more than half the population (51.2 per cent) speaking a language other than English at home. Apart from Fowler, usually the safest Labor seat in the country, the Liberals also failed to capture marginal Greenway with a candidate of Filipino descent, although it was the most marginal Labor seat to be held (Green 2013). Blacktown, in which the electorate of Greenway is located, has the largest Filipino population in Australia. However most do not live in Greenway, where they are heavily outnumbered by Indians. Moreover young Jayme Diaz had already failed in 2010. He was pushed into the seat again by his politically powerful and right-wing father, against the advice of Tony Abbott.

For some months before election day there were inspired articles about Labor losing working class western Sydney or the 'ethnic vote' (concentrated in that region) or even the 'Aboriginal vote', which is only significant in half a dozen northern electorates [Solomon, Lingiari (NT); Kennedy, Leichhardt (Qld); Kalgoorlie (WA); and Parkes (NSW)], with Indigenous populations making up over 10 per cent of the total. Aborigines are only close to an absolute majority in Lingiari, the one seat of these six held by Labor in 2010 and 2013. Inferences were wrongly drawn from New South Wales state elections in the first case and Northern Territory elections in the second.

\section{Changed faces but similar policies towards immigration and asylum}

Journalists and activists often exaggerate the excitement and changes of an election campaign. Election 2013 was not as exciting or as different as many had expected during the inordinately long campaign. Opinion polling and 
canvassing wisdom stressed that voters were interested in economic issues, job security and education, health and welfare. They generally saw the ALP as disunited and unreliable and the Liberals as a bit dubious. There was an unusual plethora of disaffected minor parties, most veering towards the right. The left was almost invisible, with the Socialist Alliance recording a minuscule national vote of 4,689. Nobody else could reasonably be described as 'left' in the old sense, unless the Murdoch caricature of the Greens is accepted. The Labor 'heartlands' of Sydney and Melbourne lost a few usually marginal suburban seats for Labor, but not very many. Eight losses were in New South Wales, half of them outside Sydney. Among them were the outer suburbs and retirement centres between Sydney and Newcastle affected by scandals surrounding Labor politicians. Many outer suburbs were also 'ethnic', especially in growing Melbourne. Queensland and Western Australia remained stolidly conservative, except for the intrusions of Bob Katter and Clive Palmer. Little changed in South Australia, with Labor losing only Hindmarsh, with a significant, but not dominant, population of 18.8 per cent speaking a language other than English at home. While there were substantial swings against Labor in many Melbourne electorates, their previous majorities were too large for them to be endangered and Green preferences often saved them.

The elephant in the room was temporarily asleep. Abbott had said 'stop the boats' often enough to get the message over. But his specific policies were provisional and unlikely to appeal to the Indonesian Government. Without negotiation they could not work. Labor politicians from the Sydney heartland were almost panicstricken. But their fears that asylum seekers were so unpopular that Labor would be slaughtered were not generally justified. Perhaps they spoke only to fellow ALP members. There was essentially no difference on asylum seekers between the parties, except that Labor wanted to lock people up on Manus Island while the Liberals favoured Nauru. Each party claimed to have done a better job in discouraging asylum seekers. Kevin Rudd went further by stating that nobody who came by boat would 'ever' be allowed into Australia. The Liberals did not go as far, knowing that 'never' is a long time in politics. Government money was lavishly spent on full-page horror advertising in the ethnic press (as well as the mainstream publications), which was otherwise less widely used than in the past, except by the Electoral Commission. Seven languages (Tamil, Sinhala, Vietnamese, Arabic, Urdu, Persian and Pushto) were used to explain in very small type that nobody who sought refuge by boat could get Australian permanent residence. What impact this might have on the target groups is not clear. Both major parties fully agreed with the message. Its main impact was likely to be on the majority population. This was no doubt intended, but could not really influence voters when the two main parties were so close. Similar 
posters in Sinhala and Tamil were displayed in Colombo (Sri Lanka), where their purpose was more obvious. A pictorial booklet aimed at Afghans appeared after the election.

Some of the speculation about immigrant sympathy with bipartisan policy was based on moving successful asylum seekers into the already small humanitarian program. This was seen by some as unfair to those waiting for their families to arrive by official channels and consequently deprived of their places in the never ending 'queue'. Another reaction may have come from Middle Eastern Christians (Maronites, Copts, Assyrians, Chaldeans) who did not welcome Arabic Muslim arrivals. But the consensus between the major parties and the complexity of affected ethnic and religious communities was such that reliable judgment of ethnic reactions proved impossible. It seems likely that differences within specific communities were more important than between communities. The divisions within the large and growing Chinese population were certainly important in Sydney, but much less so in Melbourne. There are very prosperous populations from Hong Kong, Malaysia, Singapore, Taiwan and even China itself, in electorates such as Bennelong, Menzies, Banks, Parramatta and Chisholm, all home to more than 20,000 Chinese speakers each (see Table 2). Chinese interest in the new Significant Investor visa could bring in influential and wealthy potential community leaders. If the Liberals can persuade them to see themselves as prosperous and accepted members of the middle classes, Labor could be in serious trouble in 2016. In 2013, 42 per cent of Labor lower house seats were from the two 'ethnic heartlands', most with large Chinese communities.

\section{Immediate consequences of the election}

The immediate consequences of the Liberal/National victory were a restructuring of Commonwealth departments and agencies concerned with immigrants and refugees (Refugee Council of Australia 2013); a strengthening of Operation Sovereign Borders by the creation of a military responsibility for turning back boats when safe and outside Indonesian waters; the transfer of settlement and multicultural affairs from Immigration to Social Services; the absorption of AusAID into the Department of Foreign Affairs and Trade; the movement of Customs and border control, from Attorney General's to Immigration; the transfer of the Adult Migrant English Program to the Department of Industry's vocational training; and the abolition of the small Social Inclusion Board. Of these, the implementation of Operation Sovereign Borders has caused the greatest controversy internationally. In the first week it was already being used to suppress information about boat arrivals and losses at sea, much to the indignation of journalists. The transfer of welfare services and funded organisations to Social 
Services might cause the greatest opposition from the normally quiescent service providers, withdrawn from the ambit of the Department of Immigration. Their new minister would initially be the previously controversial Kevin Andrews, supported by the equally controversial Senator Concetta Fierravanti-Wells. There is likely to be less emphasis on multiculturalism and more on national security and integration. Presumably the growth of temporary labour migration will continue, despite trade union complaints. It is not clear that the humanitarian program will be cut back to earlier levels, as threatened by Abbott. Asylum seekers will get only temporary protection visas with no right to permanence or family reunion. Large temporary populations will remain a disfranchised sector of the population. Within a month 25,000 were still in detention awaiting processing.

Within party politics a major impact of Labor's electoral defeat was to get acceptance of Rudd's system for election of the ALP party leader by party branch members and federal caucus. Increased enrolment of party members may improve ethnic candidate selection to a more representative level. But there is likely to be strong opposition to this from interested candidates. Labor has used ethnic branches for the promotion of 'mainstream' hopefuls with influence in the factions, unions and state party offices. A policy innovation, on which partisans from the major parties might well agree, is to reduce the opportunity of minor organisations to benefit from the preferential systems, especially for the Senate. There were far too many minor candidates for a stable system. None were specifically 'ethnic', despite some threats to found a Muslim party and the tiny vote for the Aboriginal First Nation Political Party (AFNPP, 1,783 votes).

In the resulting ministry of Tony Abbott, almost half the members were of Catholic religion. This was a major change from the Liberal ministers of past years, who were predominantly Protestants of English or Scottish origin. Aside from Abbott's birth in London to visiting parents, ministers and parliamentary secretaries of European origin included Eric Abetz (German-born), Mathias Cormann (Belgian-born), Arthur Sinodinos (of Greek origin) and Joe Hockey (of Armenian origin). This too marked a shift in origins from the past, although the dominance of private school and university backgrounds continued. In other parties, Ed Husic (ALP) retained Chifley (5.3 per cent Muslim population) as the national parliament's only Muslim. Zhenya Wang (Palmer United Party) became only the second China-born Senator, after the April 2014 re-election in Western Australia.

This inordinately long and tedious campaign did nothing to resolve the problem of accepting asylum seekers within the terms of the UN Convention. Indeed it returned a government that wanted an even more rigorous approach and began to implement this even before the counting was over, donating two naval vessels to Sri Lanka in November. Labor continued to depend on 'ethnic' metropolitan 
electorates but this did not produce much overt sympathy for asylum seekers. Both parties had foolishly promised that non-visa arrivals by boat would 'never' be allowed to settle in Australia, which was contrary to the ancient principle that governments cannot determine the policy of their successors. Following the Coalition's first budget, its approval began to sink in opinion polls for Commonwealth and state governments. The issues assuming prominence were jobs and welfare services rather than asylum.

\section{References}

Aston, Heath. 2013. 'Liberal candidate Andrew Nguyen says party treated ethnic candidates like "second-class citizens"'. Canberra Times, 11 September.

Cater, Nick. 2013. 'How the west was won'. Weekend Australian, 17 September.

Green, Antony. 2013. '2013 Federal Election Pendulum'. Australian Broadcasting Corporation, 30 January, viewed 19 December 2013: <blogs.abc.net.au/ antonygreen/2013/01/2013-federal-election-pendulum.html $>$.

Jakubowicz, Andrew. 2013. "How Labor won the "ethnic vote" in Western Sydney'. The Drum, 18 September, viewed 16 January 2014: < www.abc. net.au/news/2013-09-13/jakubowicz-politics-of-ethnicity/4954660>.

Jupp, James. 1981. 'The Ethnic Vote: Does it exist? A Case Study of Melbourne'. Journal of Intercultural Studies 2(3): 5-23.

Jupp, James. 1984. "The politics of "ethnic" areas of Melbourne, Sydney and Adelaide'. In John Halligan and Chris Paris (eds), Australian Urban Politics, Melbourne: Longman Cheshire.

Jupp, James. 2004. How Well Does Australian Democracy Serve Immigrant Australians? Canberra: Democratic Audit of Australia.

Jupp, James. 2012. 'Immigration Issues in the 2010 Federal Election'. In Marian Simms and John Wanna (eds), Julia 2010: The caretaker election. Canberra: ANU E-Press.

Liberal Party of Australia/National Party of Australia. 2013. The Coalition's Sovereign Borders Policy, viewed 15 December 2013: <pandora.nla.gov. au/pan/22107/20130906-0245/lpaweb-static.s3.amazonaws.com/Policies/ OperationSovereignBorders_Policy.pdf $>$.

Markus, Andrew 2013. Mapping Social Cohesion National Report. Melbourne: Monash University. 
McAllister, Ian. 1991. 'The Formation and Development of Party Loyalties: Patterns among Australian Immigrants'. ANZ Journal of Sociology 27: 195217.

McAllister, Ian. 2003. 'Border Protection, the 2001 Australian Election and the Coalition Victory'. Australian Journal of Politics and History 38(3): 445-63.

McAllister, Ian. 2011. The Australian Voter. Sydney: UNSW Press.

Nethery, Amy, Rafferty-Brown, Brynna and Taylor, Savitri. 2013. 'Exporting Detention: Australian-funded Detention in Indonesia'. Journal of Refugee Studies 26(1) March.

Parliamentary Library. 2010. Electoral division rankings: 2006 Census (2009 electoral boundaries). Research Paper no. 18, 28 May.

Patrick, Aaron. 2013. Downfall: How the Labor Party ripped itself apart. Sydney: Harper Collins/ABC Books.

Refugee Council of Australia. 2013. Changes to Immigration Portfolio: Update. Sydney: RCA, 11 October.

Simms, Marian and Wanna, John (eds). 2012. Julia 2010: The caretaker election. Canberra: ANU E-Press.

Vote Compass. 2013. 'Kevin Rudd's Asylum Seeker Policy Divides the Labor Faithful'. ABC News, 21 August, viewed 15 January 2014: <www.abc.net.au/ news/2013-08-21/asylseekers-vote-compass-boats-immigration/4899914>. 
This text taken from Abbott's Gambit: The 2013 Australian Federal Election, edited by Carol Johnson and John Wanna, published 2015 by ANU Press, The Australian National University, Canberra, Australia. 